\title{
Rumen fermentation and acetogen population changes in response to an exogenous acetogen TWA4 strain and Saccharomyces cerevisiae fermentation product ${ }^{*}$
}

\author{
Chun-lei YANG ${ }^{1}$, Le-luo GUAN ${ }^{2}$, Jian-xin LIU $^{1}$, Jia-kun $\mathrm{WANG}^{\dagger \neq 1}$ \\ ('Institute of Dairy Science, MoE Key Laboratory of Molecular Animal Nutrition, College of Animal Sciences, \\ Zhejiang University, Hangzhou 310058, China) \\ $\left({ }^{2}\right.$ Department of Agricultural, Food \& Nutritional Science, Faculty of Agricultural, Life \& Environmental Sciences, \\ University of Alberta, Edmonton, AB, T6G 2P5, Canada) \\ ${ }^{\dagger}$ E-mail: jiakunwang@zju.edu.cn \\ Received Jan. 13, 2015; Revision accepted May 15, 2015; Crosschecked July 9, 2015
}

\begin{abstract}
The presence of yeast cells could stimulate hydrogen utilization of acetogens and enhance acetogenesis. To understand the roles of acetogens in rumen fermentation, an in vitro rumen fermentation experiment was conducted with addition of acetogen strain (TWA4) and/or Saccharomyces cerevisiae fermentation product (XP). A $2 \times 2$ factorial design with two levels of TWA4 $\left(0\right.$ or $2 \times 10^{7}$ cells $\left./ \mathrm{ml}\right)$ and XP $(0$ or $2 \mathrm{~g} / \mathrm{L})$ was performed. Volatile fatty acids (VFAs) were increased $(P<0.05)$ in XP and TWA4XP, while methane was increased only in TWA4XP $(P<0.05)$. The increase rate of microorganisms with formyltetrahydrofolate synthetase, especially acetogens, was higher than that of methanogens under all treatments. Lachnospiraceae was predominant in all acetogen communities, but without close acetyl-CoA synthase (ACS) amino acid sequences from cultured isolates. Low-Acetitomaculum ruminis-like ACS was predominant in all acetogen communities, while four unique phylotypes in XP treatment were all amino acid identified low-Eubacterium limosum-like acetogens. It differs to XP treatment that more low- $A$. ruminis-like and less lowE. limosum-like sequences were identified in TWA4 and TWA4XP treatments. Enhancing acetogenesis by supplementation with an acetogen strain and/or yeast cells may be an approach to mitigate methane, by targeting proper acetogens such as uncultured low-E. limosum-like acetogens.
\end{abstract}

Key words: Acetogen, Saccharomyces cerevisiae fermentation product, Rumen fermentation, Methanogen doi: $10.1631 /$ jzus.B1500013

Document code: A

CLC number: S823

\section{Introduction}

Endogenous rumen microbiota can convert fiber to volatile fatty acid (VFA), and also result in the production of hydrogen and carbon dioxide (Kamra et al., 2012). When hydrogen builds up, it inhibits the oxidation of reduced nicotinamide adenine dinucleo-

\footnotetext{
Corresponding author

* Project supported by the Fundamental Research Funds for the Central Universities (No. 2011XZZX006), the National Natural Science Foundation of China (No. 31172229), and the University of Alberta Research Internship Program Summer 2012, Canada

(17) ORCID: Jia-kun WANG, http://orcid.org/0000-0002-7213-3721

(C) Zhejiang University and Springer-Verlag Berlin Heidelberg 2015
}

tide (NADH), leading to the accumulation of lactic acid and reduction of the fermentation (Wolin et al., 1997). To maintain a balanced environment for fermentation in the rumen, methanogens can perform methanogenesis, which converts hydrogen and carbon dioxide to methane. However, this process results in 2\%-15\% loss of feed energy (Johnson and Johnson, 1995) and exacerbation of greenhouse effects.

Recent studies have shown that hydrogen is less used for methanogenesis in the gastrointestinal tract of termites (Breznak, 1994) and Australian marsupials (Ouwerkerk et al., 2009) due to the predominant acetogenesis in the gut. Reductive acetogens are a group of bacteria that can produce acetate from hydrogen 
and carbon dioxides $\left(4 \mathrm{H}_{2}+2 \mathrm{CO}_{2} \rightarrow \mathrm{CH}_{3} \mathrm{COOH}+2 \mathrm{H}_{2} \mathrm{O}\right)$ using the acetyl-CoA pathway (Drake et al., 2006). This suggests that acetogens may serve as hydrogen sinks in experiments, which seek to lower methane emissions (van Nevel and Demeyer, 1995; Morvan et al., 1996; Joblin, 1999) in cattle. Joblin et al. (1999) has reported that methane production decreased by $97 \%$ and $64 \%$, respectively, when a Methanobrevibacter smithii sp. isolated from a grazing sheep was grown on $\mathrm{H}_{2} / \mathrm{CO}_{2}$ in vitro in the presence of a rumen acetogen isolate. Although an acetogen originating from sewage-sludge, Peptostreptococcus productus, competed successfully against methanogens in a simulated gastro-intestinal fermenter (Nollet et al., 1997a), such competition failed when in vitro ruminal digesta was used (Nollet et al., 1997b; 1998). Chaucheyras-Durand et al. (1995b) have shown that the presence of yeast cells could stimulate utilization of hydrogen by acetogens and enhance acetogenesis in an experiment utilizing a co-culture of acetogen and methanogen. Therefore, we hypothesized that the methanogenesis in the rumen is reduced by the enhanced acetogenesis with a supplement of Saccharomyces cerevisiae fermentation product (XP) and exogenous acetogens.

TWA4, a novel reductive homoacetogen isolated from forestomach contents of female tammar wallabies, could outcompete $M$. smithii in high hydrogen or heterotrophic growth on glycerol (with low hydrogen generated during fermentation) (Gagen et al., 2014). Therefore, in this study we assessed the effects of TWA4 and XP on methane production, rumen fermentation, methanogen, and acetogen population, as well as acetogenic diversity using the in vitro rumen fermentation system.

\section{Materials and methods}

\subsection{Acetogen and $S$. cerevisiae fermentation product}

TWA4 strain was kindly provided by Dr. Chris MCSWEENEY (Commonwealth Scientific and Industrial Research Organization (CSIRO), Australia) and was revived from anaerobic glycerol medium using the modified AC11.1 medium (Gagen et al., 2010) with $\mathrm{H}_{2}$ and $\mathrm{CO}_{2}$ in a proportion of $1: 3$ at $120 \mathrm{kPa}$. After growing three generations, the cell density was counted using a hemocytometer (Strober, 2001).
Original XP was supplied by Diamond V (Cedar Rapids, IA, USA).

\subsection{Experimental design}

The effects of TWA4 and XP supplementation on ruminal fermentation, methane production, methanogen population, abundance, and diversity of rumen acetogens were determined using a $2 \times 2$ factorial design using in vitro rumen fermentation system. The four treatments were the Control (without TWA4 or XP), TWA4 $\left(2 \times 10^{7}\right.$ cells $/ \mathrm{ml}$ TWA4 without XP), XP ( $2 \mathrm{~g} / \mathrm{L}$ XP without TWA4), and TWA4XP $\left(2 \times 10^{7}\right.$ cells $/ \mathrm{ml}$ TWA4 with $\left.2 \mathrm{~g} / \mathrm{L} \mathrm{XP}\right)$.

\subsection{In vitro rumen fermentation}

The rumen fluid was collected from three ruminally fistulated lactating Chinese Holstein cattle (raised in Hangzhou Zhengxing Animal Husbandry Co. Ltd., China) fed twice daily with a mixed diet (roughage: concentrate $=55: 45$ ) before morning feeding and strained through four layers of gauze into a pre-warmed and insulated bottle. The care and use of fistulated cattle was approved by the Animal Care Committee of Zhejiang University (Hangzhou, China). Rumen fluid was processed under continuous flushing with $\mathrm{CO}_{2}$. The $120 \mathrm{ml}$ serum bottle containing $0.5 \mathrm{~g}$ dry substrates $(50: 50(\mathrm{w} / \mathrm{w})$ mixture of Chinese wild rye meal and corn silage), $40 \mathrm{ml}$ buffered medium, and $10 \mathrm{ml}$ rumen fluid was anaerobically incubated at $39{ }^{\circ} \mathrm{C}$ using the semi-automated reading pressure technique (Mauricio et al., 1999). To get the final concentration of $2 \mathrm{~g} / \mathrm{L} \mathrm{XP}$ for the XP and TWA4XP treatments, $0.1 \mathrm{~g}$ XP was added into the serum bottle following the supplement of $0.5 \mathrm{~g}$ dry substrates. The $2.5 \mathrm{ml}$ growing TWA4 medium was injected into the bottle for TWA4 and TWA4XP treatments, while $2.5 \mathrm{ml}$ medium without TWA4 inoculation was injected into the control and XP treatments. A pressure transducer, connected with a computer, was used to measure the accumulated head-space gas pressure through the in vitro incubation. Gas pressure was recorded after $6,12,24$, and $48 \mathrm{~h}$ of incubation and was subsequently converted to the volumes of gas production (GP). At the same time intervals, $2 \mathrm{ml}$ of head-space gas was collected with an airtight needle (SGE Analytical Science, Australia) to measure the methane production using gas chromatography (GC-2010, Shimadzu, Kyoto, Japan) 
equipped with a Flame Ionization detector (Hu et al., 2005). For each treatment, triplicate bottles were included and three blanks were included simultaneously to correct the GP values for gas release from endogenous substrates.

At the end of incubation ( $48 \mathrm{~h}$ ), $3 \mathrm{ml}$ mixed rumen samples were collected from each bottle and three bottles were sampled under oxygen-free $\mathrm{CO}_{2}$, and immediately stored at $-80{ }^{\circ} \mathrm{C}$ to await further determination of the quantity of acetogens and methanogens, the diversity of acetogens, and the measurement of VFAs. VFAs were determined using the procedure described by $\mathrm{Hu}$ et al. (2005). Dry matter degradation (DMD) was measured using the modified nylon bag method (Goering and van Soest, 1970).

\subsection{Total DNA extraction and real-time quantita- tive polymerase chain reaction (PCR)}

Total DNA was extracted from rumen fluid collected from a 48-h incubation period using the beadbeating method as previously reported (Gagen et al., 2010). The primers specific to formyltetrahydrofolate synthetase gene ( $f h s)$ and methyl coenzyme-M reductase A ( $m c r A)$ genes (Table 1) were used to enumerate microorganisms with formyltetrahydrofolate synthetase (FTHFS) (Xu et al., 2009) and methanogens (Denman et al., 2007), respectively. The 16S rRNA gene of total bacteria was amplified with the primers as reported by Denman and McSweeney (2006) as shown in Table 1, and the copy number of total bacterial 16S rRNA gene was used as the reference to calculate the relative quantification of target. Real-time PCR was performed with SYBR green in ABI 7500 using the program: one cycle of initial denaturation at $95{ }^{\circ} \mathrm{C}$ for $10 \mathrm{~s}, 40$ cycles of denaturation at $95^{\circ} \mathrm{C}$ for $15 \mathrm{~s}$, and annealing at $60{ }^{\circ} \mathrm{C}$ for $1 \mathrm{~min}$. The relative abundance of each marker gene was estimated as: relative quantification of target $=2^{-\left(C_{\mathrm{T}} \text { target }-C_{\mathrm{T}} \text { total bacteria }\right)}$.

\subsection{Acetyl-CoA synthase gene sequencing}

To investigate the effect of TWA4 and XP on acetogen diversity, acetyl-CoA synthase (ACS) genes were amplified and sequenced from the triplicate of DNA extracted from a 48-h incubation period as previously described (Gagen et al., 2010). The amplicon triplicates from each treatment were then pooled on an equal concentration basis (Checked by Qubit 2.0, Invitrogen, USA) for clone library construction using the pGEM-T Easy ${ }^{\circledR}$ vector (Promega Co., Madison, Wisconsin, USA) and Escherichia coli competent cell DH5 $\alpha$ (TaKaRa, Dalian, China) according to manufacturer's instructions. In total, 96, 96, 94, and 92 clones were randomly sequenced from the control, TWA4, XP, and TWA4XP libraries, respectively, and were then sequenced with $\mathrm{T} 7$ primer (Beijing Genomic Institute, China). The Primer Premier 5.0 (PREMIER Biosoft International, CA, USA) was used to translate DNA sequences to amino acid sequences before alignment. Sequence similarity to ACS was determined by BLASTP analysis (Gish and States, 1993) using all existing bacterial ACS amino acid sequences in NCBI database. The ACS amino acid sequences were grouped into phylotypes at a distance of 0.01 using Jones-Taylor-Thornton Matrix of MEGA6 (Tamura et al., 2013), because Blautia schinkii and Ruminococcus obeum shared 96.3\% ACS amino acid identity, while 0.03 and 0.02 distance levels could not be clustered in our ACS amino acid sequences. The richness of ACS amino acid sequences was evaluated by the number of phylotypes and Chaol index. The evenness was analyzed by Simpon's diversity and Pielou's evenness indices, calculated from Shannon's diversity index (Felsenstein, 1993). Relative abundance of the phylotypes was determined as the sequence numbers in the phylotypes/total number of sequences. The Chao1,

Table 1 Primer sets used to amplify genes encoding total bacteria 16S rRNA, FTHFS, mcrA, and ACS in this study

\begin{tabular}{lcll}
\hline \multicolumn{1}{c}{ Target } & Direction & \multicolumn{1}{c}{ Primer sequence $\left(5^{\prime} \rightarrow 3^{\prime}\right)$} & \multicolumn{1}{c}{ Reference } \\
\hline Total bacteria & $\mathrm{F}$ & CGGCAACGAGCGCAACCC & Denman and McSweeney, 2006 \\
& $\mathrm{R}$ & CCATTGTAGCACGTGTGTAGCC & \\
FTHFS & $\mathrm{F}$ & GTWTGGGCWAARGGYGGMGAAGG & Xu et al., 2009 \\
& $\mathrm{R}$ & GARGAYGGWTTTAYATYAC & \\
\multirow{2}{*}{$\mathrm{s} A$} & $\mathrm{~F}$ & TTCGGTGGATCDCARAGRGC & Denman et al., 2007 \\
& $\mathrm{R}$ & GBARGTCGWAWCCGTAGAATCC & \\
ACS & $\mathrm{F}$ & CTBTGYGGDGCIGTIWSMTGG & Gagen et al., 2010 \\
& $\mathrm{R}$ & AARCAWCCRCADGADGTCATIGG & \\
\hline
\end{tabular}

F: forward; R: reverse; FTHFS: formyltetrahydrofolate synthetase; $m c r A$ : methyl coenzyme-M reductase A; ACS: acetyl-CoA synthase 
Simpon's and Shannon's diversity indices, Good's coverage $\left(1-n_{\text {scp }} / n_{\text {total }}, n_{\text {scp }}\right.$ is the number of single clone phylotypes and $n_{\text {total }}$ is the total number of sequences) were estimated using the summary single command in MOTHUR (Schloss et al., 2009). Unifrac.weighted in MOTHUR was used to compare the structure of acetogen community based on ACS amino acid sequences, and then to run the principal coordinates analysis $(\mathrm{PCoA})$ with the pcoa command in MOTHUR. Bootstrapped neighbour joining tree of deduced ACS amino acid sequences was constructed with MEGA 6.06 with 100 resamplings. Similar amino acid sequences identified by BLASTP analysis and ACS of TWA4 (AEL12814 and AEL12815) and Methanococcoides methylutens (KGK98586) were selected as references for tree construction. Putative ACS amino acid sequences determined in the present study have been submitted to the GenBank database under accession numbers KR152340 to KR152636.

\subsection{Statistical analyses}

Data for DMD, methane production, VFA, and abundance of acetogens and methanogens were analyzed by two-way analysis of variance in SAS 9.1 (SAS Institute Inc., Cary, NC, USA) with individual bottles as the experimental unit, TWA4 and XP supplementation as main effects, where the TWA $4 \times \mathrm{XP}$ interaction was significant, and a secondary test was conducted to separate the efficacy of TWA4 within XP (Robinson et al., 2006). Multiple comparisons means among treatments were completed by Duncan's multiple range tests. Significance was declared if $P<0.05$.

\section{Results}

\subsection{Rumen fermentation characteristics}

\subsubsection{Methane production}

The methane production ( $\mathrm{ml} / \mathrm{g}$ substrate) was not affected $(P>0.05)$ by TWA4 or XP alone except for TWA4 at $6 \mathrm{~h}$ incubation (Table 2). When supplemented with TWA4XP, methane production was increased $(P<0.05)$ at all time points by $20 \%$ to $107 \%$ compared with the control.

\subsubsection{Fermentation parameters}

DMD was not affected $(P>0.05)$ by treatments (Table 2). XP increased $(P<0.05)$ total VFA and acetate and butyrate concentrations and TWA4XP increased $(P<0.05)$ acetate, propionate, butyrate, and total VFA concentrations compared with the control. TWA4 showed no effect $(P>0.05)$ on VFA production.

Table 2 Effects of acetogen, $S$. cerevisiae fermentation product, co-addition of acetogen and yeast culture on methane emission and rumen fermentation parameters

\begin{tabular}{|c|c|c|c|c|c|c|c|c|c|c|c|c|}
\hline \multirow{3}{*}{ Parameter } & \multirow{3}{*}{ Control } & \multirow{3}{*}{ TWA4 } & \multirow{3}{*}{ XP } & \multirow{3}{*}{ TWA4XP } & \multirow{3}{*}{ SEM } & \multicolumn{7}{|c|}{$P$-value } \\
\hline & & & & & & \multirow{2}{*}{$\begin{array}{c}\text { TWA4× } \\
\text { XP }\end{array}$} & \multicolumn{3}{|c|}{ TWA4 } & \multicolumn{3}{|c|}{$\mathrm{XP}$} \\
\hline & & & & & & & Main & $+\mathrm{XP}$ & $-\mathrm{XP}$ & Main & +TWA4 & -TWA4 \\
\hline \multicolumn{13}{|c|}{$\overline{\mathrm{CH}_{4}(\mathrm{ml} / \mathrm{g} \text { substrate })}$} \\
\hline $6 \mathrm{~h}$ & $7.76 \pm 0.15^{\mathrm{c}}$ & $9.89 \pm 0.71^{\mathrm{b}}$ & $8.20 \pm 0.18^{\mathrm{c}}$ & $16.06 \pm 0.42^{\mathrm{a}}$ & 0.43 & $<0.01$ & $<0.01$ & $<0.01$ & $<0.01$ & $<0.01$ & $<0.01$ & 0.48 \\
\hline $12 \mathrm{~h}$ & $27.69 \pm 0.91^{\mathrm{b}}$ & $28.30 \pm 2.85^{\mathrm{b}}$ & $24.76 \pm 0.20^{\mathrm{b}}$ & $38.36 \pm 0.10^{\mathrm{a}}$ & 1.50 & $<0.01$ & $<0.01$ & $<0.01$ & 0.78 & $<0.05$ & $<0.01$ & 0.20 \\
\hline $24 \mathrm{~h}$ & $53.97 \pm 0.75^{\mathrm{b}}$ & $48.55 \pm 0.22^{\mathrm{b}}$ & $49.58 \pm 2.88^{\mathrm{b}}$ & $64.76 \pm 1.46^{\mathrm{a}}$ & 1.66 & $<0.01$ & $<0.05$ & $<0.01$ & 0.05 & $<0.01$ & $<0.01$ & 0.10 \\
\hline $48 \mathrm{~h}$ & $60.19 \pm 0.20^{\mathrm{b}}$ & $59.88 \pm 0.61^{\mathrm{b}}$ & $59.23 \pm 0.83^{\mathrm{b}}$ & $88.26 \pm 1.03^{\mathrm{a}}$ & 0.74 & $<0.01$ & $<0.01$ & $<0.01$ & 0.77 & $<0.01$ & $<0.01$ & 0.38 \\
\hline \multicolumn{13}{|l|}{$\mathrm{CH}_{4}(\%$ of GP $)$} \\
\hline $6 \mathrm{~h}$ & $17.12 \pm 0.17^{\mathrm{c}}$ & $20.76 \pm 0.003^{\mathrm{b}}$ & $17.70 \pm 1.47^{\mathrm{c}}$ & $27.20 \pm 0.73^{\mathrm{a}}$ & 0.77 & $<0.01$ & $<0.01$ & $<0.01$ & $<0.05$ & $<0.01$ & $<0.01$ & 0.59 \\
\hline $12 \mathrm{~h}$ & $31.44 \pm 0.75^{\mathrm{ab}}$ & $31.40 \pm 2.93^{\mathrm{ab}}$ & $29.12 \pm 0.28^{\mathrm{b}}$ & $35.35 \pm 0.04^{\mathrm{a}}$ & 1.52 & 0.07 & 0.08 & & & 0.61 & & \\
\hline $24 \mathrm{~h}$ & $40.25 \pm 0.57^{\mathrm{ab}}$ & $36.11 \pm 0.27^{\mathrm{c}}$ & $38.30 \pm 1.74^{\mathrm{bc}}$ & $39.84 \pm 1.03^{\mathrm{ab}}$ & 1.03 & $<0.05$ & 0.24 & 0.32 & $<0.05$ & 0.42 & $<0.05$ & 0.22 \\
\hline $48 \mathrm{~h}$ & $35.51 \pm 0.19^{\mathrm{b}}$ & $35.57 \pm 0.31^{\mathrm{b}}$ & $36.00 \pm 0.22^{\mathrm{b}}$ & $43.74 \pm 0.47^{\mathrm{a}}$ & 0.32 & $<0.01$ & $<0.01$ & $<0.01$ & 0.90 & $<0.01$ & $<0.01$ & 0.31 \\
\hline \multicolumn{13}{|l|}{ VFA $(\mathrm{mmol} / \mathrm{L})$} \\
\hline Total & $99.46 \pm 0.15^{\mathrm{c}}$ & $100.05 \pm 0.49^{\mathrm{c}}$ & $103.16 \pm 0.76^{b}$ & $114.94 \pm 1.08^{\mathrm{a}}$ & 0.71 & $<0.01$ & $<0.01$ & $<0.01$ & 0.58 & $<0.01$ & $<0.01$ & $<0.01$ \\
\hline Acetate (A) & $61.40 \pm 0.30^{\mathrm{c}}$ & $62.15 \pm 0.17^{\mathrm{c}}$ & $64.28 \pm 0.41^{\mathrm{b}}$ & $70.82 \pm 1.85^{\mathrm{a}}$ & 0.60 & $<0.01$ & $<0.01$ & $<0.01$ & 0.39 & $<0.01$ & $<0.01$ & $<0.01$ \\
\hline Propionate (P) & $23.11 \pm 0.15^{\mathrm{b}}$ & $23.14 \pm 0.28^{\mathrm{b}}$ & $23.63 \pm 0.30^{\mathrm{b}}$ & $27.18 \pm 0.23^{\mathrm{a}}$ & 0.25 & $<0.01$ & $<0.01$ & $<0.01$ & 0.95 & $<0.01$ & $<0.01$ & 0.18 \\
\hline Butyrate & $9.46 \pm 0.09^{c}$ & $9.47 \pm 0.08^{\mathrm{c}}$ & $10.04 \pm 0.15^{\mathrm{b}}$ & $11.07 \pm 0.28^{\mathrm{a}}$ & 0.17 & $<0.05$ & $<0.05$ & $<0.01$ & 0.96 & $<0.01$ & $<0.01$ & $<0.05$ \\
\hline $\mathrm{A}: \mathrm{P}^{*}$ & $2.66 \pm 0.03^{\mathrm{ab}}$ & $2.69 \pm 0.03^{\mathrm{ab}}$ & $2.72 \pm 0.03^{\mathrm{a}}$ & $2.61 \pm 0.03^{\mathrm{b}}$ & 0.028 & $<0.05$ & 0.17 & $<0.05$ & 0.46 & 0.76 & 0.07 & 0.14 \\
\hline DMD (\%) & $62.34 \pm 0.26$ & $61.39 \pm 2.33$ & $59.88 \pm 2.42$ & $62.59 \pm 1.67$ & 1.88 & 0.65 & 0.74 & & & 0.36 & & \\
\hline
\end{tabular}

GP: gas production; VFA: volatile fatty acids; DMD: dry matter degradation; TWA4: acetogen; XP: Saccharomyces cerevisiae fermentation product; TWA4XP: co-addition of acetogen and yeast culture; SEM: pooled standard error of the mean $(n=3)$. For the $P$-value, $\times$ : interaction; +: with supplementation; -: without supplementation. Data, shown as mean \pm standard error $(n=3)$, within a row with different superscripts differ significantly $(P<0.05)$. ${ }^{*}$ Data were expressed as proportions 


\subsection{FTHFS and methanogen abundance}

After a 48-h incubation period, the relative abundances of FTHFS and methanogens were increased $(P<0.05)$ with the addition of TWA4, XP, and TWA4XP, though relative abundance of FTHFS was much lower than methanogen abundance (Table 3). The increase in the abundance of FTHFS was greater than that of methanogens $(P<0.05)$ for $\mathrm{XP}$ and TWA4XP compared with TWA4 (Table 3). The increases of FTHFS and methanogens were $382.1 \%$ and $209.4 \%$ for TWA $4,656.0 \%$ and $478.1 \%$ for XP, and $679.1 \%$ and $421.9 \%$ for TWA4XP, respectively, compared with the control.

\subsection{Acetogen diversity}

In total, 73, 70, 74, and 80 ACS amino acid sequences were detected in the control, TWA4, XP, and TWA4XP groups, respectively. Further amino acid similarity (99\%) analysis identified 15 phylotypes for the control, 10 phylotypes for TWA4, 12 phylotypes for XP, and 7 phylotypes for TWA4XP with 3 common phylotypes among the four treatments (Table 4). Coverage analysis and a rarefaction curve indicated that the sequences obtained covered the majority of acetogen communities in all treatments with $89.0 \%$ for the control, $94.3 \%$ for TWA $4,93.2 \%$ for XP, and $95.0 \%$ for TWA4XP groups, respectively (Table 4, Fig. 1). From the results of numbers of phylotypes and Chao1, the richness of deduced ACS amino acid sequences was highest in the control group, followed by XP, TWA4, and TWA4XP. The control and XP had the highest Pielou's evenness followed by TWA4, while TWA4XP had the highest Simpson indices value.

Eight out of 22 of the phylotypes showed high (98\%-100\%) similarity to putative ACS amino acid of uncultured bacterium at GenBank uploaded by Gagen et al. (2010). All these phylotype sequences showed $62 \%-90 \%$ similarity to the nearest valid taxa including Acetitomaculum ruminis, $R$. sp. CAG:9, $R$. obeum, Eubacterium limosum, B. schinkii, B. hydrogenotrophica, and $B$. wexlerae (Table 5). Only 3 phylotypes were common phylotypes among the four treatments (Fig. 2), which occupied about $79.1 \%$ of the total ACS sequences. Phylotypes 1 and 2 had $86 \%$

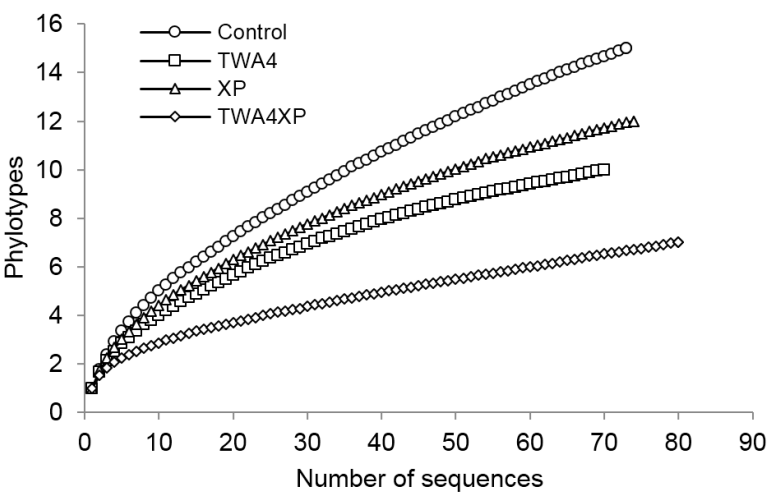

Fig. 1 Rarefaction curve of observed phylotypes of acetyl-CoA synthase generated at $99 \%$ identity cutoff value

Table 3 Least squares means of log ratio to total bacterial 16S rDNA of FTHFS and methanogen population after $48 \mathrm{~h}$ incubation

\begin{tabular}{|c|c|c|c|c|c|c|c|c|c|c|c|c|}
\hline \multirow{3}{*}{ Parameter } & \multicolumn{5}{|c|}{$\log$ ratio to total bacterial $16 \mathrm{~S}$ rDNA } & \multicolumn{7}{|c|}{$P$-value } \\
\hline & \multirow{2}{*}{ Control } & \multirow{2}{*}{ TWA4 } & \multirow{2}{*}{$\mathrm{XP}$} & \multirow{2}{*}{ TWA4XP } & \multirow{2}{*}{ SEM } & \multirow{2}{*}{$\begin{array}{c}\text { TWA4× } \\
\text { XP }\end{array}$} & \multicolumn{3}{|c|}{ TWA4 } & \multicolumn{3}{|c|}{$\mathrm{XP}$} \\
\hline & & & & & & & Main & $+\mathrm{XP}$ & $-\mathrm{XP}$ & Main & +TWA4 & -TWA4 \\
\hline FTHFS & $-6.88 \pm 0.035^{\mathrm{c}}$ & $-6.19 \pm 0.023^{b}$ & $-6.19 \pm 0.023^{\mathrm{a}}$ & $-5.98 \pm 0.019^{\mathrm{a}}$ & 0.026 & $<0.01$ & $<0.01$ & 0.72 & $<0.01$ & $<0.01$ & $<0.01$ & $<0.01$ \\
\hline Methanogen & $-2.57 \pm 0.165^{\mathrm{c}}$ & $-2.01 \pm 0.020^{\mathrm{b}}$ & $-1.73 \pm 0.037^{\mathrm{a}}$ & $-1.78 \pm 0.022^{\mathrm{a}}$ & 0.086 & $<0.01$ & $<0.05$ & 0.73 & $<0.01$ & $<0.01$ & 0.09 & $<0.01$ \\
\hline
\end{tabular}

Table 4 Acetogen community diversity indices of four treatments at $99 \%$ cutoff

\begin{tabular}{lcccccc}
\hline Treatment & No. of OTUs & Chaol & Shannon & Pielou's evenness & Simpson & Good's coverage \\
\hline Control & 15 & 22.0 & 1.89 & 0.61 & 0.23 & 89.0 \\
TWA4 & 10 & 13.0 & 1.48 & 0.58 & 0.32 & 94.3 \\
XP & 12 & 14.5 & 1.62 & 0.61 & 0.30 & 93.2 \\
TWA4XP & 7 & 13.0 & 0.96 & 0.37 & 0.51 & 95.0 \\
\hline
\end{tabular}

OTUs: operational taxonomic units. Good's coverage $\left(1-n_{\text {scp }} / n_{\text {total }}, n_{\text {scp }}\right.$ is the number of single clone phylotypes and $n_{\text {total }}$ is the total number of sequences) was estimated using the summary.single command of MOTHUR. The Pielou's evenness was estimated as Shannon/ln(Chao1). The total number of sequences was 73, 70, 74, and 80 in the control, TWA4, XP, and TWA4XP treatments, respectively 


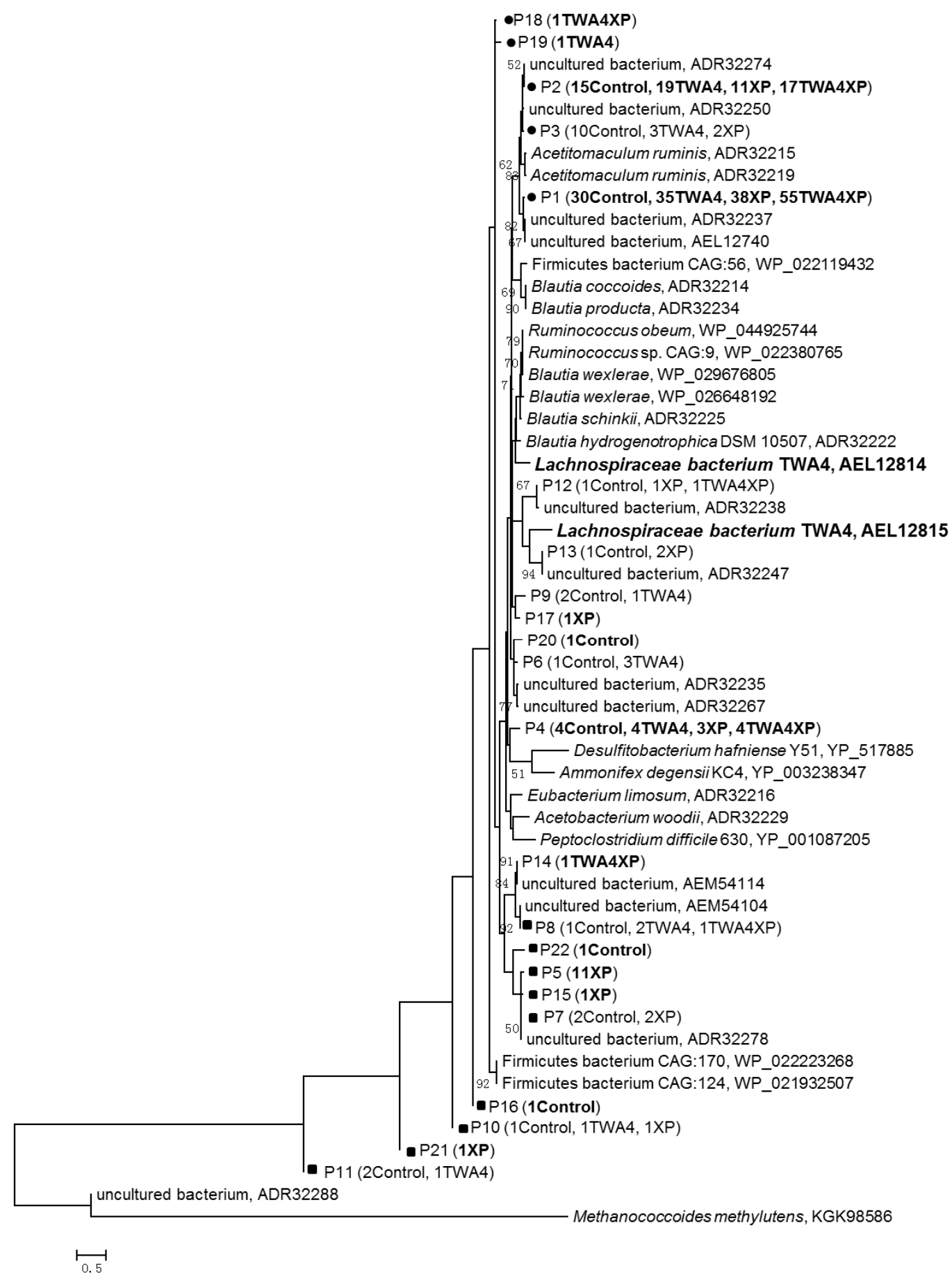

Fig. 2 Phylogenetic analysis of deduced acetyl-CoA synthase amino acid sequences

$\mathrm{P}$ is the phylotypes generated at $99 \%$ identity cutoff value. GenBank accession numbers of reference sequences are shown after the species names. Bootstap values of $\geq 50 \%$ are shown at the nodes. The low- $A$. ruminis-like sequences and low-E. limosum-like sequences are marked with solid circles $(\bullet)$ and squares $(\bullet)$, respectively 
Table 5 Phylotype distribution of acetyl-CoA synthase between individual treatments

\begin{tabular}{|c|c|c|c|c|c|c|c|c|c|}
\hline \multirow[b]{2}{*}{ Phylotype } & \multirow[b]{2}{*}{$\begin{array}{c}\text { Total } \\
\text { Clones }\end{array}$} & \multirow[b]{2}{*}{ Control } & \multirow[b]{2}{*}{ TWA4 } & \multirow[b]{2}{*}{$\mathrm{XP}$} & \multirow[b]{2}{*}{ TWA4XP } & \multicolumn{2}{|l|}{ Nearest valid taxa } & \multicolumn{2}{|l|}{ Nearest relative } \\
\hline & & & & & & Description & $\begin{array}{l}\text { Identity } \\
(\%)\end{array}$ & Description & $\begin{array}{l}\text { Identity } \\
(\%)\end{array}$ \\
\hline 1 & 158 & 30 & 35 & 38 & 55 & $\begin{array}{l}\text { A. ruminis, } \\
\text { ADR32215 }\end{array}$ & 86 & $\begin{array}{l}\text { Uncultured bacterium, } \\
\text { ADR } 32256\end{array}$ & 96 \\
\hline 2 & 62 & 15 & 19 & 11 & 17 & $\begin{array}{l}\text { A. ruminis, } \\
\text { ADR32215 }\end{array}$ & 86 & $\begin{array}{l}\text { Uncultured bacterium, } \\
\text { ADR } 32274\end{array}$ & 98 \\
\hline 3 & 15 & 10 & 3 & 2 & 0 & $\begin{array}{l}\text { A. ruminis, } \\
\text { ADR32215 }\end{array}$ & 90 & $\begin{array}{l}\text { Uncultured bacterium, } \\
\text { ADR } 32250\end{array}$ & 98 \\
\hline 4 & 15 & 4 & 4 & 3 & 4 & $\begin{array}{l}\text { B. schinkii, } \\
\text { ADR32225 }\end{array}$ & 76 & $\begin{array}{l}\text { B. schinkii, } \\
\text { ADR32225 }\end{array}$ & 76 \\
\hline 5 & 11 & 0 & 0 & 11 & 0 & $\begin{array}{l}\text { E. limosum, } \\
\text { ADR32216 }\end{array}$ & 70 & $\begin{array}{l}\text { Uncultured bacterium, } \\
\text { ADR } 32288\end{array}$ & 96 \\
\hline 6 & 4 & 1 & 3 & 0 & 0 & $\begin{array}{l}\text { B. hydrogenotrophica, } \\
\text { ADR } 32222\end{array}$ & 84 & $\begin{array}{l}\text { Uncultured bacterium, } \\
\text { ADR } 32235\end{array}$ & 90 \\
\hline 7 & 4 & 2 & 0 & 2 & 0 & $\begin{array}{l}\text { E. limosum, } \\
\text { ADR32216 }\end{array}$ & 72 & $\begin{array}{l}\text { Uncultured bacterium, } \\
\text { ADR } 32278\end{array}$ & 100 \\
\hline 8 & 4 & 1 & 2 & 0 & 1 & $\begin{array}{l}\text { E. limosum, } \\
\text { ADR32216 }\end{array}$ & 62 & $\begin{array}{l}\text { Uncultured bacterium, } \\
\text { AEM54104 }\end{array}$ & 100 \\
\hline 9 & 3 & 2 & 1 & 0 & 0 & $\begin{array}{l}\text { B. hydrogenotrophica, } \\
\text { ADR } 32222\end{array}$ & 79 & $\begin{array}{l}\text { Uncultured bacterium, } \\
\text { ADR } 32267\end{array}$ & 82 \\
\hline 10 & 3 & 1 & 1 & 1 & 0 & $\begin{array}{l}\text { E. limosum, } \\
\text { ADR32216 }\end{array}$ & 65 & $\begin{array}{l}\text { Firmicutes bacterium } \\
\text { CAG:124, WP_021932507 }\end{array}$ & 73 \\
\hline 11 & 3 & 2 & 1 & 0 & 0 & $\begin{array}{l}\text { E. limosum, } \\
\text { ADR32216 }\end{array}$ & 68 & $\begin{array}{l}\text { Firmicutes bacterium } \\
\text { CAG:170, WP_022223268 }\end{array}$ & 76 \\
\hline 12 & 3 & 1 & 0 & 1 & 1 & $\begin{array}{l}\text { B. wexlerae, } \\
\text { WP } 026648192\end{array}$ & 77 & $\begin{array}{l}\text { Uncultured bacterium, } \\
\text { ADR32238 }\end{array}$ & 98 \\
\hline 13 & 3 & 1 & 0 & 2 & 0 & $\begin{array}{l}\text { R. ó̄eum, } \\
\text { WP_044925744 }\end{array}$ & 73 & $\begin{array}{l}\text { Uncultured bacterium, } \\
\text { ADR } 32247\end{array}$ & 100 \\
\hline 14 & 1 & 0 & 0 & 0 & 1 & $\begin{array}{l}\text { B. hydrogenotrophica, } \\
\text { ADR } 32222\end{array}$ & 66 & $\begin{array}{l}\text { Uncultured bacterium, } \\
\text { AEM54114 }\end{array}$ & 100 \\
\hline 15 & 1 & 0 & 0 & 1 & 0 & $\begin{array}{l}\text { E. limosum, } \\
\text { ADR32216 }\end{array}$ & 69 & $\begin{array}{l}\text { Uncultured bacterium, } \\
\text { ADR } 32278\end{array}$ & 98 \\
\hline 16 & 1 & 1 & 0 & 0 & 0 & $\begin{array}{l}\text { E. limosum, } \\
\text { ADR32216 }\end{array}$ & 68 & $\begin{array}{l}\text { Firmicutes bacterium } \\
\text { CAG:124, WP_021932507 }\end{array}$ & 73 \\
\hline 17 & 1 & 0 & 0 & 1 & 0 & $\begin{array}{l}R \text {. sp. CAG:9, } \\
\text { WP_022380765 }\end{array}$ & 83 & $\begin{array}{l}R \text {. sp. CAG: } 9, \\
\text { WP_022380765 }\end{array}$ & 83 \\
\hline 18 & 1 & 0 & 0 & 0 & 1 & $\begin{array}{l}\text { A. ruminis, } \\
\text { ADR32219 }\end{array}$ & 73 & $\begin{array}{l}\text { Firmicutes bacterium } \\
\text { CAG:170, WP_022223268 }\end{array}$ & 79 \\
\hline 19 & 1 & 0 & 1 & 0 & 0 & $\begin{array}{l}\text { A. ruminis, } \\
\text { ADR32219 }\end{array}$ & 70 & $\begin{array}{l}\text { Firmicutes bacterium } \\
\text { CAG:170, WP_022223268 }\end{array}$ & 76 \\
\hline 20 & 1 & 1 & 0 & 0 & 0 & $\begin{array}{l}\text { B. wexlerae, } \\
\text { WP_029676805 }\end{array}$ & 80 & $\begin{array}{l}\text { Uncultured bacterium, } \\
\text { ADR32267 }\end{array}$ & 86 \\
\hline 21 & 1 & 0 & 0 & 1 & 0 & $\begin{array}{l}\text { E. limosum, } \\
\text { ADR32216 }\end{array}$ & 73 & $\begin{array}{l}\text { E. limosum, } \\
\text { ADR32216 }\end{array}$ & 73 \\
\hline 22 & 1 & 1 & 0 & 0 & 0 & $\begin{array}{l}\text { E. limosum, } \\
\text { ADR32216 }\end{array}$ & 69 & $\begin{array}{l}\text { Uncultured bacterium, } \\
\text { ADR } 32288\end{array}$ & 81 \\
\hline Total & 297 & 73 & 70 & 74 & 80 & & & & \\
\hline
\end{tabular}

similarity with A. ruminis, $96 \%$ and $98 \%$ similarities with uncultured bacterium. Phylotype 4 had $76 \%$ similarity with B. schinkii (Table 5).

Based on amino acid identified phylotypes, uncultured bacteria sequences were predominant in all acetogen communities. The dominant acetogens were unchanged in the treatments (phylotypes 1 and 2; Table 5 and Fig. 3) while the acetogen communities were significantly different among four treatments (weighted significance $<0.001$; Fig. $3 b$ ), whose community changes were reflected in the appearance new phylotypes. For XP treatment, about all the four unique phylotypes were identified as low-E. limosumlike acetogens (Table 5). There were no TWA4 ACS amino acid sequences actually recovered in the TWA4 and TWA4XP libraries (Fig. 2). 
(a)
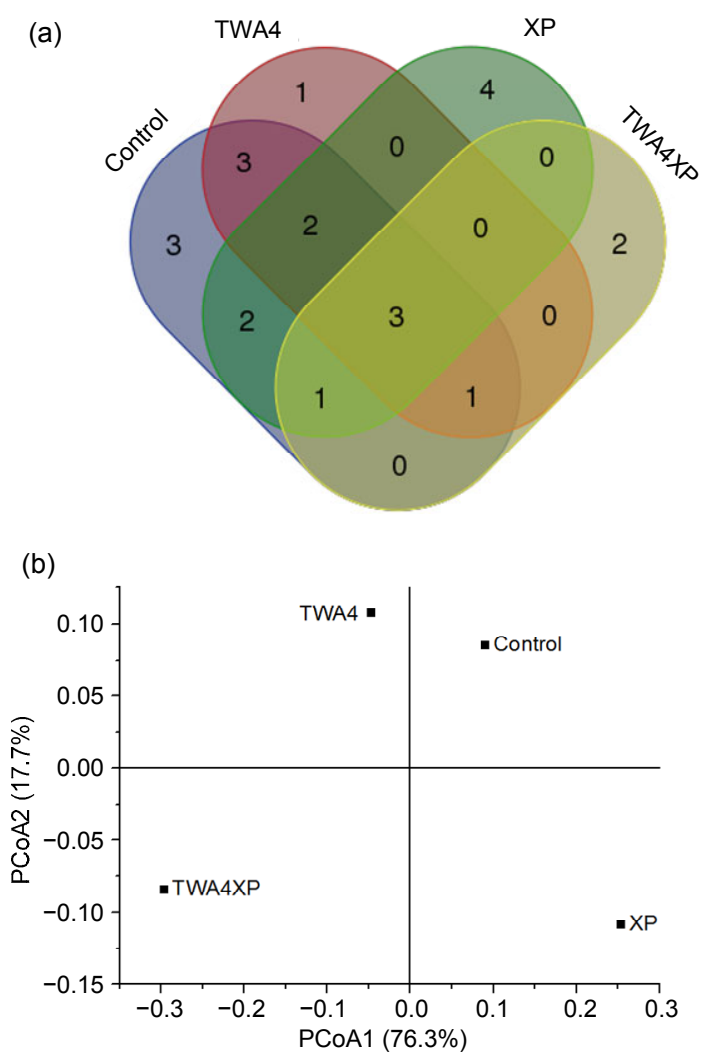

Fig. 3 Unique and common acetyl-CoA synthase phylotypes identified in the four treatments (a), and the principal coordinates analysis (PCoA) for the four treatments (b)

\section{Discussion}

Ruminal methane production through enteric fermentation is of global concern due to its contribution to greenhouse gas emission as well as accounting for dietary energy loss in animals. Since the 1950s much effort has been expended trying to reduce methane emission from ruminants. Although the use of agents including chemicals and antibiotics has been successful, their use has been limited due to the probability of high quantities of residuals remaining in the animal products and feces (Kobayashi, 2010; Patra, 2012). Methanogenesis is the primary method of facilitating the consumption of hydrogen in the rumen, followed by fumarate reduction (Asanuma and Hino, 2000; Mitsumori and Sun, 2008), sulfate reduction (Morvan et al., 1996; Sahakian et al., 2010), nitrate and nitrite reduction (Sakthivel et al., 2012), and reductive acetogenesis (Henderson et al., 2010). Evidence from in vitro incubations of rumen contents
(Nollet et al., 1997a; le Van et al., 1998) and methanogen-free lambs (Fonty et al., 2007) indicates that acetogens can function as hydrogenotrophs to suppress methanogenesis. Thus, enhancing reductive acetogenesis in the rumen may be an effective strategy to mitigate methane.

Lopez et al. (1999) investigated the ability of six reductive acetogens to prevent the accumulation of methane in vitro and found that only two of them, E. limosum strains ATCC 8486 and Ser 5, decreased methane production by about $5 \%$ after a $24-\mathrm{h}$ incubation period, while total VFA was not affected $(P>$ 0.05 ) by the addition of the six acetogens. As with Lopez's study, the addition of TWA4 alone did not change the methane and VFA production in our experiment. The TWA4, XP, and TWA4XP failed to improve the DMD, revealing that no additional hydrogen and nutrients were produced from the substrates in these treatments compared with the control.

Yeast, as a feed additive, has been confirmed as being able to provide nutrients and vitamins to microorganisms (Chaucheyras-Durand et al., 1995a). Chaucheyras-Durand and Fonty (2001) reported that the supplementation of S. cerevisiae CNCM I-1077 tended to improve the in sacco degradation of wheat straw, and increased VFA production. From that study, Lascano and Heinrichs (2009) reported $S$. cerevisiae yeast culture increased rumen VFA concentration without influencing DMD. They concluded that the increased total VFA concentration with unchanged molar proportions of individual VFA was the result of the increased fermentation rate created by yeast culture supplement. However, reasons for inconsistency between the increased fermentation rate and unchanged DMD were not explained. As with the above study, our results showed that DMD remained unchanged, suggesting that the increased VFA by XP addition or XP and TWA4 co-addition was not a product of fermentable organic matter, such as cellulose or starch.

Chaucheyras-Durand et al. (1995b) showed that the presence of yeast cells stimulated the utilization of hydrogen by acetogens and enhanced acetogenesis, in a co-culture of acetogens and methanogens. In our XP and TWA4XP treatments, the increased VFA was mainly due to the acetate (Table 2). With the fhs primers of Xu et al. (2009), the rate of acetogen increase was higher than that of methanogens in XP and 
TWA4XP, suggesting that XP treatments may alter the acetogen communities and increase acetogenesis. However, according to Gagen et al. (2010), the fhs primers used to enumerate acetogens in our experiment could recover partial FTHFS sequence from a wider range of rumen acetogens, although multiple spurious amplicons could be generated from some acetogens and rumen microbial DNA. Until now, no appropriate real-time PCR primers were reported for acetogens, it could only deduce that XP treatments may increase the FTHFS biochemical pathway of rumen microorganisms, especially acetogens, which would cause an increase in VFA production.

The diversity of the acetogen community in our experiment showed that Lachnospiraceae was the dominant acetogen in the rumen fermentation system, but without close sequences from cultured isolates, which was similar to the results of Gagen et al. (2010) However, the species richness of our experiment was lower than that of Gagen et al. (2010). This difference may be due to the production accumulation in vitro system. It is possible that TWA4 could not survival after a 48-h fermentation period; however, the acetogen community was significantly changed by adding TWA4 alone or with XP, and therefore we posit that future studies are needed to track the fate of TWA4 with the change of fermentation time.

Acetogen phylotypes were increased by the addition of XP (Table 5 and Fig. 3a) with four unique phylotypes where amino acid was identified as lowE. limosum-like acetogen (Table 5). E. limosum and A. ruminis were all isolates from rumen by Sharak Genthner et al. (1981) and Greening and Leedle (1989), respectively. These bacteria can utilize $\mathrm{H}_{2} / \mathrm{CO}_{2}$, one-carbon compounds, to produce acetate. However, in contrast to A. ruminis, E. limosum can utilize amino acid to produce acetate and butyrate, and its growth can be stimulated by amino acids (Sharak Genthner et al., 1981; Pacaud et al., 1985). Amino acids were a substrate for methanogen growth and methanogensis (Mathrani and Boone, 1985; Chaucheyras-Durand et al., 1995b) as well. Therefore, enhancing acetogenesis by supplement with acetogen strain and/or yeast cells may be a way of mitigating methane, targeting acetogens such as E. limosum which utilize substrates such as amino acids to facilitate growth and acetogenesis. In order to further support our speculation, future experiments should next try isolating the low-E. limosum-like acetogens to test their nutritional characteristics and competition with methanogens.

\section{Conclusions}

The efficacy of adding TWA4 alone in the in vitro rumen fermentation system was limited, while with the substrate provided by XP, TWA4 could enhance acetogenesis by changing the acetogen community to low- $A$. ruminis-like acetogens. However, methanogenesis in rumen was enhanced by the co-addition. The XP addition could enhance acetogenesis with unchanged methanogenesis by changing the acetogen community to low-E. limosum-like acetogens, suggesting that enhancing acetogenesis by supplementation with acetogen strain and/or yeast cells may be a way to mitigate methane, with proper targeted acetogens such as the uncultured lowE. limosum-like acetogens.

\section{Acknowledgements}

The authors are grateful to Dr. Ilkyu YOON at Diamond $\mathrm{V}$, Cedar Rapids, for donating the XP used for this study and his suggestions and advice, to Dr. Chris MCSWEENEY at CSIRO, Australia, for his critical reading of and editorial corrections to the manuscript, and to Ms. Yan-hong CHEN, at University of Alberta, Canada, for her technical guidance.

\section{Compliance with ethics guidelines}

Chun-lei YANG, Le-luo GUAN, Jian-xin LIU, and Jia-kun WANG declare that they have no conflict of interest.

All management and experimental procedures were approved by the Animal Care Committee of Zhejiang University, China and were carried out in accordance with the University's guidelines for animal research.

\section{References}

Asanuma, N., Hino, T., 2000. Activity and properties of fumarate reductase in ruminal bacteria. J. Gen. Appl. Microbiol., 46(3):119-125. [doi:10.2323/jgam.46.119]

Breznak, J.A., 1994. Acetogenesis from carbon dioxide in termite guts. In: Drake, H.L. (Ed.), Acetogenesis. Chapman and Hall, New York, p.303-330.

Chaucheyras-Durand, F., Fonty, G., 2001. Establishment of cellulolytic bacteria and development of fermentative activities in the rumen of gnotobiotically-reared lambs receiving the microbial additive Saccharomyces cerevisiae CNCM I-1077. Reprod. Nutr. Dev., 41(1):57-70. [doi:10.1051/rnd:2001112]

Chaucheyras-Durand, F., Fonty, G., Bertin, G., et al., 1995a. 
Effects of live Saccharomyces cerevisiae cells on zoospore germination, growth, and cellulolytic activity of the rumen anaerobic fungus, Neocallimastix frontalis $\mathrm{MCH} 3$. Curr. Microbiol., 31(4):201-205. [doi:10.1007/BF00298 373]

Chaucheyras-Durand, F., Fonty, G., Bertin, G., et al., 1995b. In vitro $\mathrm{H}_{2}$ utilization by a ruminal acetogenic bacterium cultivated alone or in association with an archaea methanogen is stimulated by a probiotic strain of Saccharomyces cerevisiae. Appl. Environ. Microbiol., 61:3466-3467.

Denman, S.E., McSweeney, C.S., 2006. Development of a real-time PCR assay for monitoring anaerobic fungal and cellulolytic bacterial population within the rumen. FEMS Microbiol. Ecol., 58(3):572-582. [doi:10.1111/j.15746941.2006.00190.x]

Denman, S.E., Tomkins, N.W., McSweeney, C.S., 2007. Quantitation and diversity analysis of ruminal methanogenic populations in response to the antimethanogenic compound bromochloromethane. FEMS Microbiol. Ecol., 62(3):313-322. [doi:10.1111/j.1574-6941.2007.00394.x]

Drake, H.L., Küsel, K., Matthies, C., 2006. Acetogenic prokaryotes. In: Dworkin, M., Falkow, S., Rosenberg, E., et al. (Eds.), The Prokaryotes. Springer, US, Vol. 2, p.354-420. [doi:10.1007/0-387-30742-7_13]

Felsenstein, J., 1993. Phylip (Phylogeny Inference Package) Version 3.57c. Department of Genetics, University of Washington, Seattle. Available from http://evolution. genetics.washington.edu/phylip.html [Accessed on Jan. 1, 2015].

Fonty, G., Joblin, K., Chavarot, M., et al., 2007. Establishment and development of ruminal hydrogenotrophs in methanogen-free lambs. Appl. Environ. Microbiol., 73(20): 6391-6403. [doi:10.1128/AEM.00181-07]

Gagen, E.J., Denman, S.E., Padmanabha, J., et al., 2010. Functional gene analysis suggests different acetogen populations in the bovine rumen and tammar wallaby forestomach. Appl. Environ. Microbiol., 76(23):77857795. [doi:10.1128/AEM.01679-10]

Gagen, E.J., Wang, J.K., Padmanabha, J., et al., 2014. Investigation of a new acetogen isolated from an enrichment of the tammar wallaby forestomach. BMC Microbiol., 14(1): 314. [doi:10.1186/s12866-014-0314-3]

Gish, W., States, D.J., 1993. Identification of protein coding regions by database similarity search. Nat. Genet., 3(3): 266-272. [doi:10.1038/ng0393-266]

Goering, H.K., van Soest, P.J., 1970. Forage Fiber Analyses (Apparatus, Reagents, Procedures, and Some Applications). Agriculture Handbook No. 379, Agriculture Research Service, USDA, p.387-598.

Greening, R.C., Leedle, J.A.Z., 1989. Enrichment and isolation of Acetitomaculum ruminis, gen. nov., sp. nov.: acetogenic bacteria from the bovine rumen. Arch. Microbiol., 151(5):399-406. [doi:10.1007/BF00416597]

Henderson, G., Naylor, G.E., Leahy, S.C., et al., 2010. Presence of novel, potentially homoacetogenic bacteria in the rumen as determined by analysis of formyltetrahydro- folate synthetase sequences from ruminants. Appl. Environ. Microbiol., 76(7):2058-2066. [doi:10.1128/AEM. 02580-09]

Hu, W.L., Liu, J.X., Ye, J.A., et al., 2005. Effect of tea saponins on rumen fermentation in vitro. Anim. Feed Sci. Technol., 120(3-4):333-339. [doi:10.1016/j.anifeedsci. 2005.02.029]

Joblin, K., 1999. Ruminal acetogens and their potential to lower ruminant methane emissions. Crop Pasture Sci., 50(8):1307-1314. [doi:10.1071/AR99004]

Johnson, K.A., Johnson, D.E., 1995. Methane emissions from cattle. J. Anim. Sci., 73:2483-2492.

Kamra, D., Pawar, M., Singh, B., 2012. Effect of plant secondary metabolites on rumen methanogens and methane emissions by ruminants. In: Patra, A.K. (Ed.), Dietary Phytochemicals and Microbes. Springer Netherlands, p.351-370. [doi:10.1007/978-94-007-3926-0_12]

Kobayashi, Y., 2010. Abatement of methane production from ruminants: trends in the manipulation of rumen fermentation. Asian-Aust. J. Anim. Sci., 23(3):410-416. [doi:10. 5713/ajas.2010.r.01]

Lascano, G.J., Heinrichs, A.J., 2009. Rumen fermentation pattern of dairy heifers fed restricted amounts of low, medium, and high concentrate diets without and with yeast culture. Livest. Sci., 124(1-3):48-57. [doi:10.1016/j. livsci.2008.12.007]

le Van, T.D., Robinson, J.A., Ralph, J., et al., 1998. Assessment of reductive acetogenesis with indigenous ruminal bacterium populations and Acetitomaculum ruminis. Appl. Environ. Microbiol., 64(9):3429-3436.

Lopez, S., McIntosh, F., Wallace, R., et al., 1999. Effect of adding acetogenic bacteria on methane production by mixed rumen microorganisms. Anim. Feed. Sci. Technol., 78(1-2):1-9. [doi:10.1016/S0377-8401(98)00273-9]

Mathrani, I.M., Boone, D.R., 1985. Isolation and characterization of a moderately halophilic methanogen from a solar saltern. Appl. Environ. Microbiol., 50:140-143.

Mauricio, R.M., Mould, F.L., Dhanoa, M.S., et al., 1999. A semi-automated in vitro gas production technique for ruminant feedstuff evaluation. Anim. Feed Sci. Technol., 79(4):321-330. [doi:10.1016/S0377-8401(99)00033-4]

Mitsumori, M., Sun, W., 2008. Control of rumen microbial fermentation for mitigating methane emissions from the rumen. Asian-Aust. J. Anim. Sci., 21(1):144-154. [doi:10. 5713/ajas.2008.r01]

Morvan, B., Bonnemoy, F., Fonty, G., et al., 1996. Quantitative determination of $\mathrm{H}_{2}$-utilizing acetogenic and sulfatereducing bacteria and methanogenic archaea from digestive tract of different mammals. Curr. Microbiol., 32(3):129-133. [doi:10.1007/s002849900023]

Nollet, L., Velde, I.V., Verstraete, W., 1997a. Effect of the addition of Peptostreptococcus productus ATCC 35244 on the gastro-intestinal microbiota and its activity, as simulated in an in vitro simulator of the human gastrointestinal tract. Appl. Microbiol. Biot., 48(1):99-104. [doi:10.1007/s002530051022] 
Nollet, L., Demeyer, D., Verstraete, W., 1997b. Effect of 2-bromoethanesulfonic acid and Peptostreptococcus productus ATCC 35244 addition on stimulation of reductive acetogenesis in the ruminal ecosystem by selective inhibition of methanogenesis. Appl. Environ. Microbiol., 63(1):194-200.

Nollet, L., Mbanzamihigo, L., Demeyer, D., et al., 1998. Effect of the addition of Peptostreptococcus productus ATCC 35244 on reductive acetogenesis in the ruminal ecosystem after inhibition of methanogenesis by cell-free supernatant of Lactobacillus plantarum 80. Anim. Feed Sci. Technol., 71(1-2):49-66. [doi:10.1016/S0377-8401(97) 00135-1]

Ouwerkerk, D., Maguire, A., McMillen, L., et al., 2009. Hydrogen utilising bacteria from the forestomach of eastern grey (Macropus giganteus) and red (Macropus rufus) kangaroos. Anim. Prod. Sci., 49(11):1043-1051. [doi:10. 1071/EA08294]

Pacaud, S., Loubiere, P., Goma, G., 1985. Methanol metabolism by Eubacterium limosum B2: effects of $\mathrm{pH}$ and carbon dioxide on growth and organic acid production. Curr. Microbiol., 12(5):245-250. [doi:10.1007/BF01567 972]

Patra, A.K., 2012. Enteric methane mitigation technologies for ruminant livestock: a synthesis of current research and future directions. Environ. Monit. Assess., 184(4):19291952. [doi:10.1007/s10661-011-2090-y]

Robinson, P.H., Wiseman, J., Udén, P., et al., 2006. Some experimental design and statistical criteria for analysis of studies in manuscripts submitted for consideration for publication. Anim. Feed Sci. Technol., 129(1-2):1-11. [doi:10.1016/j.anifeedsci.2006.05.011]

Sahakian, A.B., Jee, S.R., Pimentel, M., 2010. Methane and the gastrointestinal tract. Digest. Dis. Sci., 55(8):21352143. [doi:10.1007/s10620-009-1012-0]

Sakthivel, P.C., Kamra, D.N., Agarwal, N., et al., 2012. Effect of sodium nitrate and nitrate reducing bacteria on in vitro methane production and fermentation with buffalo rumen liquor. Asian-Aust. J. Anim. Sci., 25(6):812-817. [doi:10. 5713/ajas.2011.11383]

Schloss, P.D., Westcott, S.L., Ryabin, T., et al., 2009. Introducing mothur: open-source, platform-independent, community-supported software for describing and comparing microbial communities. Appl. Environ. Microbiol., 75(23):7537-7541. [doi:10.1128/AEM.01541-09]

Sharak Genthner, B.R., Davis, C., Bryant, M.P., 1981. Features of rumen and sewage sludge strains of Eubacterium limosum, a methanol-and $\mathrm{H}_{2}-\mathrm{CO}_{2}$-utilizing species. Appl. Environ. Microbiol., 42(1):12-19.

Strober, W., 2001. Monitoring cell growth. In: Coligan, J.E., Bierer, B.E., Margulies, D.H., et al. (Eds.), Current Protocols in Immunology. John Wiley \& Sons, USA. [doi:10.1002/0471142735.ima03as21]

Tamura, K., Stecher, G., Peterson, D., et al., 2013. MEGA6: molecular evolutionary genetics analysis version $6.0 \mathrm{Mol}$.
Biol. Evol., 30(12):2725-2729. [doi:10.1093/molbev/ mst197]

van Nevel, C., Demeyer, D.I., 1995. Lipolysis and biohydrogenation of soybean oil in the rumen in vitro: inhibition by antimicrobials. J. Dairy Sci., 78(12):2797-2806. [doi:10.3168/jds.S0022-0302(95)76910-7]

Wolin, M., Miller, T., Stewart, C., 1997. Microbe-microbe interactions. In: Hobson, P.N., Stewart, C.S. (Eds.), The Rumen Microbial Ecosystem. Blackie Academic \& Professional, London, an imprint of Chapman \& Hall, p.467-491. [doi:10.1007/978-94-009-1453-7_11]

Xu, K., Liu, H., Du, G., et al., 2009. Real-time PCR assays targeting formyltetrahydrofolate synthetase gene to enumerate acetogens in natural and engineered environments. Anaerobe, 15(5):204-213. [doi:10.1016/j.anaerobe. 2009.03.005]

\section{中文概要}

\section{题 目: 外源添加产乙酸菌和酿酒酵母发酵物对瘤胃发酵 特性及产乙酸菌菌群结构的影响}

目 的: 酵母可以促进产乙酸菌利用氢生成乙酸。为了解 产乙酸菌在瘤胃发酵中的作用, 本试验研究了产 乙酸菌单独添加及其与酿酒酵母发酵物联合添 加对瘤胃发酵特性及产乙酸菌菌群结构的影响。

创新点: 通过瘤胃甲烷生成量与产乙酸菌菌群结构关联, 揭示降低瘤胃甲烷生成的新途径。

方 法: 试验采用 $2 \times 2$ 双因素试验设计, 产乙酸菌 TWA4 的添加量为 0 和 $2 \times 10^{7} \mathrm{cells} / \mathrm{ml}$, 酿酒酵母发酵物 $X P$ 的添加量为 0 和 $2 \mathrm{~g} / \mathrm{L}$ 。

结 论: 瘤胃体外发酵研究发现, 单独添加 XP 以及 TWA4 和 XP 联合添加可增加挥发性脂肪酸产量 $(P<0.05)$, TWA4 和 XP 联合添加显著增加了 甲烷生成量 $(P<0.05)$ 。单独添加 TWA4、XP 以及两者联合添加均增加了含有甲酰四氢叶酸 合成酶的微生物的数量, 尤其是产乙酸菌的数 量, 这类微生物的增长幅度高于产甲烷菌。各处 理产乙酸菌均以 Lachnospiraceae 为主, 但与已培 养的微生物的相似性较低。与 Acetitomaculum ruminis 低相似性的一类未知的产乙酸菌在各处 理中均占优势, 但 XP 的添加增加了与 Eubacterium limosum 低相似未知产乙酸菌的数 量。与 XP 不同, TWA4 及其与 XP 的联合添加使 与 A. ruminis 低相似性的一类未知的产乙酸菌的 数量增加, 与 E. limosum 低相似未知产乙酸菌的 数量降低。因此, 添加与 E. limosum 低相似的未 知产乙酸菌和 (或) 酵母可能是降低瘤胃甲烷生 成的一种有效途径。

关键词: 产乙酸菌; 酿酒酵母发酵物; 瘤胃发酵; 产甲烷菌 